\title{
CATARACT EXTRACTION UNDER COMBINED LOCAL AND GENERAL ANALGESIA USING PHENAZOCINE*
}

\author{
BY \\ G. T. WILLOUGHBY CASHELL AND K. BRYN THOMAS \\ Royal Berkshire Hospital, Reading
}

THE recent introduction of a powerful general analgesic drug, phenazocine ("Narphen"), with a potency stated to be seven to ten times that of morphine (Eckenhoff, 1959) has enabled us to make use of its unique properties in ophthalmic surgery. The drug possesses fewer undesirable side-effects on respiration and on the circulation than morphine or pethidine, and does not produce vomiting, an important factor in ophthalmic surgery.

One of us has reported 150 cases in which it was used as an adjunct to general anaesthesia (Thomas, 1962a), and 120 ophthalmic cases, which included 102 cataract extractions (Thomas, 1962b).

We have now increased this series to 200 cases of cataract extraction and 54 others (Table I).

The ages of the patients were between 23 and 93 years (average $72 \cdot 1$ ), and the majority of the older patients (104 over 70 years) presented the common picture of failing circulation with hypertension, and chronic pulmonary disease.

Pre-medication.-Only light preoperative sedation is used, the patients receiving promethazine 25 or $50 \mathrm{mg}$., and promazine 25 or $50 \mathrm{mg}$., according to age and physical status, by mouth, 2 hours before operation. The avoidance of heavy premedication with barbiturates and/or morphine derivatives, forms an important part of a technique in which post-operative restlessness and TABLE I

OPHTHALMIC OPERATIONS UNDER "NARPHEN" ANALGESIA

\begin{tabular}{|c|c|c|}
\hline \multicolumn{2}{|l|}{ Lens extraction } & 200 \\
\hline $\begin{array}{l}\text { Iridectomy } \\
\text { Scheie's operation } \\
\text { Cyclodialysis } \\
\text { Cyclodiathermy } \\
\text { Division of synechiae } \\
\text { Needling of lens } \\
\text { Suture of cornea } \\
\text { Removal of corneal sutures } \\
\text { Corneal graft } \\
\text { Sclerectomy } \\
\text { Scleral resection } \\
\text { Abscission of prolapsed iris }\end{array}$ & $\begin{array}{r}11 \\
4 \\
9 \\
10 \\
1 \\
2 \\
1 \\
1 \\
1 \\
12 \\
1 \\
1\end{array}$ & 54 \\
\hline Total & & 254 \\
\hline
\end{tabular}
vomiting are reduced to negligible proportions.

Technique.-In the operating theatre, the patient is given $0.5-1.5 \mathrm{mg}$. phenazocine intravenously. The drug is supplied in ampoules containing $2 \mathrm{mg}$. in $1 \mathrm{ml}$., and it is convenient to dilute with water to $4 \mathrm{ml}$. The needle is kept in the vein. The dose is regulated according to age, weight, and physical state, and represents $0.01 \mathrm{mg} / \mathrm{kg}$. 
body weight, but the dosage does not appear to be critical. Levallorphan is a specific antidote. At least 5 minutes after the injection, the local nerve blocks are introduced by the surgeon, retrobulbar injection of 1 per cent. lignocaine with hyaluronidase being followed by facial block, and small wheal injections of the eyelid margins with the same solution, to take the retraction sutures. In some cases, the latter may be omitted, the general analgesia being sufficient to allow the placing and retention of these sutures without pain.

It is important that the 5-minute time interval be allowed fully to elapse, in order that the phenazocine may take effect before the local blocks are placed. It may profitably be lengthened by giving the injection in the ward 10 or 15 minutes before operation.* The reaction of the patient to the local needle pricks is noted (see Table II). As a rule, it is barely noticeable, in marked contrast to the state of affairs when no general analgesia is used. If the patient reacts then a further $0.5 \mathrm{mg}$. phenazocine is given, and this may be repeated if required during the operation, but is rarely needed. The total dose may vary from 1 to $3 \mathrm{mg}$. (the latter was required in one case only). The usual dosage is $1.5 \mathrm{mg}$., usually in two doses of 1 and $0.5 \mathrm{mg}$. For the remainder of the operation, the patient will lie still, breathing easily and gently, and occasionally snoring softly, though easily roused and capable of responding if need be. It is scarcely necessary to add that extraneous noises and surgical chat should be avoided.

Side-effects.-No effect on blood pressure or circulation has been apparent. Slight respiratory depression, manifested chiefly by a slowing in rate, has occurred. In two cases, $1 \mathrm{mg}$. levallorphan was given intravenously to counteract respiratory depression, which responded rapidly (Table II, opposite).

The duration of operation in the 200 cases of cataract extraction was 15 to 30 minutes (average 24), at the end of which the patient is double-padded and returned quietly to bed, where the quiet analgesic state continues for an hour or more.

Operative Technique.-In almost all the cases referred to this has been the same. Following the local injections and the introduction of retraction sutures in the eyelids, a Graefe section is performed with a good conjunctival flap, and a full upward iridectomy. This is followed by the introduction of alpha-chymotrypsin into the anterior chamber, and the application of three corneo-scleral sutures under the conjunctival flap using Barraquer virgin silk on a Grieshaber cataract needle. After 3 minutes the anterior chamber is irrigated with Ringer's solution to remove the trypsin and the lens is extracted by the intracapsular method. In the elderly, a simple expression of the lens usually suffices. In younger patients the intracapsular forceps of Duthie are used, and if the lens is swollen with a tense capsule the erisophake is employed. After the extraction, the corneo-scleral sutures are tied, the conjunctival flap is smoothed back into place, the iris is adjusted with a repositor, and air is introduced into the anterior chamber. Atropine and penicillin drops are instilled and the patient is double padded for 24 hours, at the end of which time the pad on the un-operated eye is removed.

\footnotetext{
* Kenny (1963) has recently described a technique in which the phenazocine is given intramuscularly with the premedication.
1 hour before operation.
} 
TABLE II

EFFECT ON RESPIRATORY RATE IN 21 CONSECUTIVE CASES OF CATARACT EXTRACTION UNDER "NARPHEN"

\begin{tabular}{|c|c|c|c|c|c|c|}
\hline \multirow{2}{*}{$\begin{array}{l}\text { Age } \\
\text { (yrs) }\end{array}$} & \multirow{2}{*}{ Sex } & \multirow{2}{*}{$\begin{array}{l}\text { Dose of } \\
\text { "Narphen" } \\
\text { (mg.) }\end{array}$} & \multicolumn{2}{|c|}{ Respiratory Rate (min.) } & \multirow{2}{*}{$\begin{array}{l}\text { Reaction to } \\
\text { Needle Prick }\end{array}$} & \multirow{2}{*}{ Notes } \\
\hline & & & Pre-operative & Lowest & & \\
\hline 57 & $\mathbf{M}$ & $1 \cdot 5^{*}$ & $18 / \mathrm{min}$ & $16 / \mathrm{min}$ & Slight & \\
\hline 75 & $\mathbf{F}$ & 1 & 20 & 18 & Nil & \\
\hline 75 & $\mathbf{M}$ & $1 \cdot 5^{*}$ & 22 & 18 & Slight & \\
\hline 84 & $\mathbf{M}$ & $1 \cdot 0$ & 22 & 19 & Nil & \\
\hline 56 & $\mathbf{M}$ & $2 \cdot 0^{*}$ & 20 & 14 & Slight & \\
\hline 79 & $\mathrm{~F}$ & 1 & 22 & 18 & Nil & \\
\hline 74 & $\mathbf{M}$ & $2 *$ & 22 & 16 & Slight & $\begin{array}{l}\text { Premedication with Nembutal } \\
1.5 \mathrm{gr} \text {. }\end{array}$ \\
\hline 84 & $\mathbf{F}$ & 1 & 24 & 20 & Nil & \\
\hline 78 & $\mathbf{F}$ & $1 \cdot 5^{*}$ & 20 & 18 & Nil & $\begin{array}{l}\text { "Squeezed" during operation. } \\
\text { Slight vitreous loss. }\end{array}$ \\
\hline 75 & $\mathbf{M}$ & $2 *$ & 20 & 14 & "It's sharp" & Very nervous patient \\
\hline 71 & $\mathrm{~F}$ & $2^{*}$ & 22 & 6 & Groaned & $\begin{array}{l}\text { Levallorphan } 1 \mathrm{mg} \text {. increased } \\
\text { rate to } 12 \text { in } 1 \frac{1}{2} \text { min. Asth- } \\
\text { matic. Very poor risk. }\end{array}$ \\
\hline 72 & $\mathbf{M}$ & $1 \cdot 25^{*}$ & 20 & 12 & Slight & $\begin{array}{l}\text { Respiratory rate rapidly re- } \\
\text { turned to } 18\end{array}$ \\
\hline 76 & $\mathrm{~F}$ & 1 & 24 & 18 & Nil & \\
\hline 84 & $\mathrm{~F}$ & 1 & 24 & 20 & Nil & \\
\hline 74 & $\mathbf{F}$ & $1 \cdot 5^{*}$ & 22 & 20 & Nil & \\
\hline 31 & $\mathrm{~F}$ & $1 \cdot 75^{*}$ & 26 & 16 & Nil & $\begin{array}{l}\text { Respiratory rate increased to } 18 \\
\text { after } 5 \mathrm{~min} \text {. }\end{array}$ \\
\hline 73 & $\mathbf{F}$ & 1 & 26 & 22 & Nil & \\
\hline 68 & $F$ & $1 \cdot 5^{*}$ & 18 & 16 & Nil & \\
\hline 62 & $F$ & 1 & 22 & 18 & Nil & \\
\hline 83 & $\mathrm{~F}$ & 1 & 16 & 16 & Nil & \\
\hline 77 & $\mathbf{M}$ & $1 \cdot 5^{*}$ & 22 & 18 & Nil & \\
\hline
\end{tabular}

"Divided doses of "Narphen". 
Post-operative Complications.-Complications possibly referable to the analgesic technique have been encountered in three cases. A man aged 67, a chronic bronchitic, had two post-operative episodes of pallor and sweating, with slight cyanosis after scleral diathermy. He was given intravenous levallorphan $1 \mathrm{mg}$. and oxygen, with improvement, but it is doubtful whether the episode was connected with the administration of phenazocine. A woman aged 81 was sick on the day following cataract extraction, having told the anaesthetist before the operation that she was "always sick". Another woman aged 83, with chronic bronchitis and bronchiectasis, suffered a flare up of her pulmonary condition 2 days after cataract extraction. These three patients were all eventually discharged with satisfactory operative results.

Two asthmatic patients had minor attacks of asthma within 2 days of operation, but there is no reason to connect these with the drugs given. Seven other asthmatic patients had no post-operative sequelae.

The post-operative surgical complications in this series have been few. There were four cases of slight vitreous loss after extraction, due to rupture of the hyaloid; in one of these, the lens had dislocated backwards into the posterior chamber and required removal with a vectis. There was one case of prolapse of one pillar of the iris the day after operation, due to restlessness, but abscission of the prolapse was performed under phenazocine with a final visual result of 6/4. Three cases of mild uveitis occurred, one of which was due to rupture of the capsule at operation leaving some lens matter behind in the anterior chamber. There was one case of macular haemorrhage in a diabetic and one of choroidal detachment which eventually subsided.

Contraindications.-There seem to be no contraindications to the use of this technique. Some of these patients suffered from Stokes-Adams' syndrome (1 case), diabetes ( 27 cases), and bronchiectasis ( 1 case) and the majority showed signs of gross cardiovascular and/or pulmonary disease.

\section{Summary}

A technique for analgesia for intra-ocular surgery is described. Following light premedication, the patient is given $1.0 \mathrm{mg}$. phenazocine intravenously, followed 5 minutes later by retrobulbar, facial, and eyelid block with 1 per cent. lignocaine. Further doses of $0.5 \mathrm{mg}$. phenazocine are given if necessary.

The patients are very quiet during operation and post-operative complications are minimal. Vomiting is very rare. Respiratory depression, if marked, is effectively countered by levallorphan.

\section{REFERENCES}

ECKenhoff, J. E. (1959). Anesthesiology, 20, 355.

KenNy, S. (1963). Brit. J. Anaesth., 35, 317.

Tномаs, K. B. (1962a). Ibid., 34, 336.

(1962b). Acta anaesth. scand., Suppl. 12, p. 110. 